Maurer School of Law: Indiana University

Digital Repository @ Maurer Law

$6-2015$

\title{
Lessons from Pollution Control: Response to Heller and Hobbs 2014
}

Robert L. Fischman

Indiana University Maurer School of Law, rfischma@indiana.edu

James Salzman

Duke Law School, salzman@law.duke.edu

Follow this and additional works at: https://www.repository.law.indiana.edu/facpub

Part of the Biology Commons, Environmental Law Commons, Natural Resources and Conservation Commons, Natural Resources Law Commons, and the Natural Resources Management and Policy

Commons

\section{Recommended Citation}

Fischman, Robert L. and Salzman, James, "Lessons from Pollution Control: Response to Heller and Hobbs 2014" (2015). Articles by Maurer Faculty. 2995.

https://www.repository.law.indiana.edu/facpub/2995

This Article is brought to you for free and open access by the Faculty Scholarship at Digital Repository @ Maurer Law. It has been accepted for inclusion in Articles by Maurer Faculty by an authorized administrator of Digital Repository @ Maurer Law. For more information, please contact rvaughan@indiana.edu. 


\title{
Lessons from pollution control: Response to Heller and Hobbs 2014
}

\author{
Robert L. Fischman* 9 and James Salzman† \\ ${ }^{*}$ Maurer School of Law, Indiana University, 211 S. Indiana Av., Bloomington, IN 47405, U.S.A. \\ †Nicholas School of the Environment, School of Law, Duke University, P.O. Box 90360, Durham, NC 27708, U.S.A.
}

Heller and Hobbs (2014) provide an incisive analysis of the challenges inherent in setting endpoint states as conservation goals. The social construct of nature, nonequilibrium ecosystems, global climate change, large-scale transformations of the landscape, and increasing population and economic activity confound efforts to establish conservation goals. Stakeholders often disagree on endpoint targets, whereas competing notions of historic fidelity and future flexibility frustrate our ability to articulate success, never mind actually achieve it. As Heller and Hobbs describe, this leaves managers in the bind of finding the "balance between future-looking management emphasizing change and past-looking management emphasizing persistence." As a result, decisions over when and how to intervene are particularly difficult.

In place of endpoint goals, Heller and Hobbs call for management intervention known as natural practice (NP), which emphasizes less intensive methods and embodies an ethic of virtue. This approach is both problematic and promising.

It is problematic because it ignores the very challenge Heller and Hobbs have so well identified. They propose $\mathrm{NP}$ as a substitute for managing with endpoint targets, but then do the exact opposite. In describing how to apply an NP approach, they claim that NP "may be best suited for conservation areas committed to the preservation of holistic nature and wilderness, rather than single species targets." Wilderness preservation is nothing if not an endpoint goal. Indeed, difficult though they may be to set, endpoint goals are inescapable in conservation. The NP framework suggests useful questions to ask when intervening, but it cannot answer the more fundamental challenges of whether to intervene and why. For that, one needs to know what is being managing for-the endpoint. Endpoint goals, athough difficult to set, will necessarily play a role in conservation. But arguments and uncertainty over endpoints need not halt action.

Although it does not solve the fundamental challenge of setting endpoint goals, Heller and Hobbs' proposal for NP holds promise. Their approach can draw from decades of experience in pollution control guided by a similar strategy, known as best management practice (BMP) or best available technology (BAT). The practice of abating emissions at a specific source without knowing exactly how it affects broader endpoint goals allowed pollution control law to move forward, even as the establishment of endpoint objectives remained contentious. The NP approach may similarly help managers act despite pervasive uncertainty over endpoint goals.

Environmental law has always employed ambientbased standards and aspirational goals as endpoints. These are evident in water quality standards that articulate the uses that a water body will support and the broader goals of fishable, swimmable waters (16 U.S.C. $\S 1251$ and 1313). The day-to-day management of environmental quality, however, relies not on these endpoint goals, but on a practice approach that all users of the environment should engage in cautionary or remedial steps to avoid degradation. Requiring polluters to use BAT or BMP, regardless of a traceable impact, avoided the difficulties of identifying the site-specific mechanisms by which many small contributors to environmental degradation combined to create human health problems and ecological impairment (Houck 1994; Babich 2003). Technology-based limitations for discharges to waters from point sources of pollution (and their counterparts in air and soil contamination) profoundly transformed environmental law and remain the most widely used tools in the environmental manager's kit. 
As Heller and Hobbs note, such a shift from endpoint goal attainment to a practice-based approach involves ethics as well as management. In pollution control, abating discharges without mandating across-the-board improved practices demands proof of causation to ensure that no one has to incur costs unless a preponderance of the evidence traces an activity directly to a harm (Fischman 2008). A related utilitarian principle would find justification for imposing costs only where benefits outweigh them (Sagoff 1988). Ambient-based standards establish the environmental quality desired while permitting so-called efficient pollution that does not prevent their attainment. The release of a contaminant in an amount that causes less harm than would be caused by abating the emission is an example of efficient pollution. The endpoint goal approach asks managers to focus on the larger consequences of their actions. But multiple, interacting causes-often with latent consequences unperceivable for a long time-make proof of causation infeasible in most cases. This difficulty led lawmakers to require economically practical steps to be taken without linking cause to endpoint effects in any particular place.

Asking all actors to act with consideration of possible effects (e.g., through BAT), regardless of a traceable impact on the endpoint goals, is a Kantian, deontological ethic of right action (Sagoff 1988). This reflects a similar ethical stance to the one Heller and Hobbs offer for NP: acting out of the virtues that reflect conservation (e.g., humility). In the case of pollution control, humility requires abating similar dischargers in a like manner because of only modest understanding of the ultimate causes of environmental quality impairment. The conflicts between utilitarian and deontological approaches to conservation have spurred many scholarly debates (e.g., Daly 1995). But, in the practical realm of management and implementation, both principles coexist. Indeed, they are mutually supportive.

There are a few lessons from environmental law that may help advance Heller and Hobbs' project. First, process-based standards for action are especially valuable because they do not require much tailoring to particular circumstances. Although place-based variations in treatments are important, insisting on too much tailoring undermines the advantage of uniform practices. It is better to shift the burden to demonstrate the need for a variance from a BMP than to require managers to show why the practice offers advantages in a particular application. Dischargers subject to a BAT standard under the U.S. Clean Water Act may obtain a modification from the practice-based requirements for certain nonconventional pollutants if they can show that, among other things, the modification will not interfere with the attainment of water quality standards (33 U.S.C. \$ 1311 [g][2]). A similar approach might require loggers to leave a certain width of uncut areas along creeks unless they can demonstrate that a narrower strip would yield sufficient progress toward aquatic endpoint goals.

In addressing air pollution, the causation problems are even more vexing because the behavior of the atmosphere is more difficult to model than water flows. Here, the law employs both a BAT approach (e.g., through New Source Performance Standards for categories of stationary sources) and an ambient-based approach (through the National Ambient Air Quality Standards applied in state implementation plans) (42 U.S.C. \$S $7409 \& 7411$ ).

This dual strategy leads to our second point: processbased standards should serve as floors for environmental management, not ceilings. Under the Clean Water Act, technology-based limitations are required in almost all circumstances, even if it is unclear whether they translate into a contribution toward achieving ambient water quality standards. When BAT standards are inadequate to ensure water quality, agencies must impose additional restrictions (33 U.S.C. \ 1312). Similarly, although NP may be a good way to assess interventions, additional action may be needed to achieve specific goals, such as sustaining a local population of a desired species.

For example, although the U.S. Endangered Species Act (ESA) prohibits activities that result in injury to individuals of a listed species as a result of habitat modification, the issues of proof often thwart enforcement (Fischman 2008). In an attempt to promote recovery without having to prove an endpoint violation, the federal government has sought to incorporate some process-based tools to protect species from private actions. For example, a recent rule for the Lesser Prairie-Chicken (Tympanuchus pallidicinctus) shields from ESA liability oil drillers operating in accordance with the BMP contained in a conservation plan (Department of the Interior, Fish and Wildlife Service 2014). If the practices fail to abate the decline of the prairie-chicken population, the U.S. Fish and Wildlife Service will need to promulgate a new rule. A better process-based standard would incorporate a response to continued population decline in the rule itself. For example, if the BMP fails to prevent population decline, then the rule might require a temporary reduction in drilling density while BMPs undergo review and adjustment.

A weakness of process-based abatement in pollution control law offers a lesson for adoption of NP in conservation. Chemical concentrations are relatively easy to measure and provide numerical standards for evaluating whether endpoint objectives are achieved. But many water quality goals are biological (33 U.S.C. \$1251[a]). The BAT approach has often served, in practice, as both the floor and ceiling in aquatic restoration because standards defining the endpoint goals for the biological integrity of waters are too vague (Adler 2003). Implementation of the Clean Water Act operated on autopilot, requiring BATs without much regard for whether these practices sufficiently restored biological integrity. Only recently 
have ecological problems, such as excess nutrients in the Chesapeake Bay or Gulf of Mexico, spurred greater attention to controlling the threats to biological objectives that have not been addressed through BAT. Still the U.S. Environmental Protection Agency has required very few numerical criteria to measure progress toward biological objectives (Houck 2014). NP in conservation addresses precisely this situation, where endpoint goals are imprecise at best and self-contradictory at worst. A corollary of the second lesson, then, is that difficult-todefine objectives are nonetheless important ceilings that demand greater attention to keep the practice-based actions on track to achieve biological goals. This requires managers to reconcile competing visions for conservation by establishing goals and to translate the goals into technical criteria that can be monitored. As difficult as this task may be, it remains essential to all environmental policy, including conservation.

Third, many best practices may be decidedly low tech. For instance, nonpoint source contributions to water quality impairment are often controlled with buffer strips of planted vegetation or grading. Simple, clear BMPs for conducting agriculture, silviculture, and even residential and commercial development may prove most effective in reducing the myriad stressors on protected areas from the surrounding matrix of more intensively modified, nonconservation lands. For example, although oil and gas extraction technology is complex, the best conservation practices are often simple tweaks. Limiting drilling to $1 \mathrm{rig} / \mathrm{section}$ (sections are 1 square mile), with surface impacts on $<3 \%$ of the area, in places with Sage Grouse (Centrocercus urophasianus) leks is easy to implement and monitor (Sage-grouse National Technical Team 2011). Similarly, screening openings in heatertreaters used in the oil extraction industry is a simple practice that improves migratory bird conservation (U.S. Court of Appeals 2010).
Heller and Hobbs' NP model provides a promising approach to moving forward incrementally in the face of uncertainty. The lessons from pollution control caution that biological goals, fuzzy though they may be, remain important polestars for management. NP may be imperfect, but it is a sensible and meaningful direction in which to nudge conservation if paired with meaningful objectives.

\section{Literature Cited}

Adler RW. 2003. The two lost books in the water quality trilogy: the elusive objectives of physical and biological integrity. Environmental Law 33:29-78.

Babich A. 2003. Too much science in environmental law. Columbia Journal of Environmental Law 28:119-184.

Daly HE. 1995. Reply to Mark Sagoff's "Carrying capacity and ecological economics". BioScience 45:621-624.

Department of the Interior, Fish and Wildlife Service. 2014. Special rule for the lesser prairie-chicken. Federal Register 79:2007320085.

Fischman RL. 2008. The divides of environmental law and the problem of harm in the Endangered Species Act. Indiana Law Journal 83: 661-693.

Heller NE, Hobbs RJ. 2014. Development of a natural practice to adapt conservation goals to global climate change. Conservation Biology 28:696-704.

Houck OA. 1994. Of bats, birds, and B-A-T: the convergent evolution of environmental law. Mississippi Law Journal 63:403-471.

Houck OA. 2014. Cooperative federalism, nutrients, and the Clean Water Act: three cases revisited. Environmental Law Reporter (Environmental Law Institute) 44:10426-10442.

Sage-grouse National Technical Team. 2011. A report on national greater sage-grouse conservation measures. Available from http://www. blm.gov/pgdata/etc/medialib/blm/co/programs/wildlife.Par.73607. File.dat/GrSG\%20Tech\%20Team\%20Report.pdf (accessed August 2014).

Sagoff M. 1988. The economy of the earth: philosophy, law, and the environment. Cambridge University Press, New York.

U.S. Court of Appeals. 2010. United States v. Apollo Energies, 611 F.3d 679 (10th Circuit). 